\title{
THE CONCEPT OF ECONOMIC-MANAGERIAL GOODWILL: INTERNATIONAL BIBLIOGRAPHIC RESEARCH
}

\author{
Ivana Podhorska ${ }^{1, a,{ }^{,},}$Svitlana Bilan ${ }^{2, b}$, and Catalin Ionita ${ }^{3, c}$ \\ ${ }^{1}$ University of Zilina, Faculty of Operation and Economics of Transport and Communications, \\ Department of Economics, Univerzitna 1, 01026 Zilina \\ ${ }^{2}$ Rzeszów University of Technology, al. Powstańców Warszawy 12, 35-959 Rzeszów, Poland \\ ${ }^{3}$ Doctoral School in Management, National School of Political and Administrative Studies, Bucharest, \\ Romania

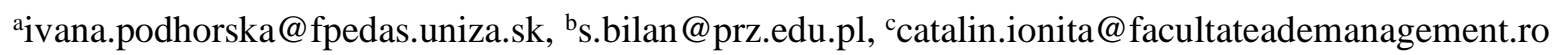 \\ *Corresponding author
}

Cite as: Podhorska, I., Bilan, S., Ionita, C. (2021). The concept of economic-managerial goodwill: International bibliographic research, Ekonomicko-manazerske spektrum, 15(2), 111-125.

Available at: dx.doi.org/10.26552/ems.2021.2.111-125

Received: 28 April 2021; Received in revised form: 30 June 2021; Accepted: 5 July 2021; Available online: 30 December 2021

\begin{abstract}
:
Research background: The concept of goodwill has been a major economic problem for over 200 years. Goodwill creation and quantification is interdisciplinary, for example, in accounting, economics, and marketing. Goodwill is an intangible asset associated with the purchase of a company. Specifically, goodwill is the portion of the purchase price that is higher than the sum of the net fair value of all assets purchased in the acquisition and the liabilities assumed in the process. The value of a company's brand name, robust customer base, good customer relations, commendable employee relations, and proprietary technology represent a few reasons why goodwill exists.

Purpose: Broadly, the value of company goodwill increases the company's overall market value. In both economic theory and practice, this situation can arise where there is a difference between the company's market value and book value. Any debate about goodwill is reasonable because the origin of goodwill can be defined, but an interpretation of its value is always a challenge.

Methods: This study analyses scientific three databases, namely Web of Science, Scopus, and Social Science Research Network, applying descriptive statistics and science maps. In addition, the study provides a holistic overview of the historical development of the concept of goodwill from 1842 to the present.

Findings and value-added: The study works with VOSviewer software. The results provide a holistic overview of the evolution of the concept of goodwill in the scientific community and demonstrate its significant role in the world of science from 1842 to the present.
\end{abstract}

Keywords: goodwill, literature review, VosViewer, descriptive statistics, science maps

JEL Classification: G3, G32, G34 
The concept of economic-managerial goodwill:

International bibliographic research

Authors: Ivana Podhorska, Svitlana Bilan,

Catalin Ionita

\section{Introduction}

In the literature, there are many definitions of intangibles assets. According to Mooney (2008), Siegel and Shim (2000) and Andrews and De Serres (2012), intangible assets have no physical substance and represent a right granted by the government or by another company. Also, Augier and Teece (2005) define intangible assets as non-current assets and different from tangible (physical) assets because they are used by one party, their transfer costs are hard to calibrate, their property rights are limited, and the enforcement of property rights is relatively difficult (Ocak and Findik, 2019).

According to Gardberg, (2006) and Wyatt (2005) there are many types of intangible assets such as patents, copyright, trademarks, design, mineral exploration, brand, software, formula, trade secrets, capitalized research and development, databases, domain, human capital, motion pictures, consumer lists, customer loyalty, licenses, market share, marketing rights and goodwill. According to Ionita and Dinu (2021), intangible assets should be identifiable, should be controlled by the firm, and should provide future economic benefits to the firm, and the cost of intangible assets can be measured reliably if firms report these kinds of items as an asset.

Company goodwill represents an actual topic that includes details such as company reputation, image, prestige, or brand. Goodwill may affect company relationships with partners, such as customers, suppliers, financial institutions, and the general public (Corbae and D'Ersamo, 2021). Research is mainly focused on goodwill that is generated internally, which meaning and quantification still represent a managerial challenge, because it may content any items, tangible and intangible character which add the value to company. In contrast, purchased goodwill is a term recognized in accounting and represents a part of the purchase price a company pays to acquire another. Specifically, goodwill is greater than the net fair value of its assets. At the same time, its value must be identified separately. Below, we will discuss the term 'Goodwill'. (Gupta and Van Nieuwerburgh, 2021; Janoskova and Kral, 2019).

The earliest known commercial use of 'goodwill' was in 1571, although the notion it conveys is probably much older. However, when Francis read a paper on goodwill to the Chartered Accountants' Students' Society of Edinburgh in 1891, he felt the need to preface his remarks on valuation with an apology. He regretted his inability to quote any authority on the subject. $\mathrm{He}$ was unaware of any previous writings on goodwill valuation. The earlier writings on goodwill concentrated on legal aspects, particularly the protection of attendant property rights. If anyone had considered the impact of different factors on price and how goodwill may be valued in the absence of direct evidence of a market transaction, his opinion seems to have remained unpublished. (More, 1891) Twenty-three years after the appearance of More's paper, P. D. Leake (1921) first published his view on the valuation of goodwill in a paper read to the Leicester Chartered Accountants' Students' Society. During the intervening period, however, the subject seems to have aroused considerable interest, and several writings included a discussion on it. Several factors have contributed to this surge of interest. An increasing number of accountants joined professional societies, many of which had been founded in the decade or so before 1891 (Leake, 1921). There followed more organised opportunities for exchanging ideas within the profession and a greater concern for the attainment of acceptable standards of performance in professional duties. Consequently, the number of writings on accounting grew in number. (Andersson et al., 2021)

The main aim of this study is to provide a historical review of scientific literature dealing with the concept of goodwill from 1842 to the present. This study analyses scientific databases - Web of Science, Scopus, and Social Science Research Network. The study methods include descriptive statistics and science maps. VOSviewer software is applied to extract data. The 
results provide a holistic view of the evolution of the issue of goodwill in the scientific community and demonstrate its significant role in the world of science.

\section{Literature review}

The first accounting paper dealing with goodwill 'Law and Practice in Connection with Goodwill' was published in 1884 by W. Harris in journal 'The Accountants' Students Journal' Subsequently, a number of other papers were published within a short time, for example, 'Goodwill' was published by J. H. Bourn in 1888; 'Goodwill' by F. More was published in 1891, and 'Goodwill and Its Treatment in Accounts' by L. R. Dicksee was published in 1897; in 1898, E. Guthrie published his paper on 'Goodwill'. During the same time, several papers and studies on the concept of goodwill were also published in non-English speaking countries such as Germany and France entitled 'Kundschaft', 'Clientèle', and 'Renommée' (Bhandari and McGrattan, 2021).

Earlier, the issue of company goodwill was developed in two directions: legal and economic. The legal direction was among the first of these.

Figure 1: The beginnings of goodwill in scientific literature

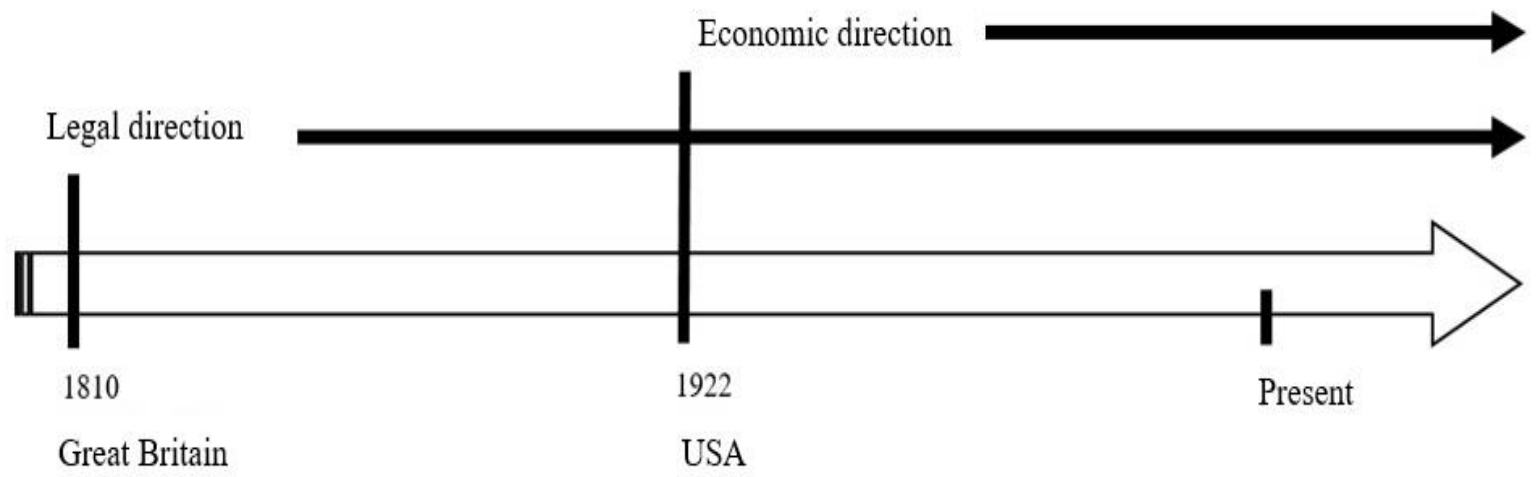

Source: Processed by authors

In 1842, Lord Eldon, a pioneer in the area of legal direction, described company goodwill as follows: 'Company goodwill, which is the subject of supply and demand, is the probability that old customers come back to old places, nothing more...

In 1901, Lord Macnaghten, Inland Revenue Commissioners (IRC) vs. Muller and Co's Margarine Ltd., described company goodwill: 'What is goodwill? It is something very simple to describe and very difficult for definition, on the other hand. Goodwill is the benefit of a company's reputation and business relationships' (Bhandari and McGrattan, 2021).

The second, economic direction, had a different view of company goodwill. In 1922, W. A. Paton, founder of journal, 'The Accounting Review', defined company goodwill in 'Ronald Press': 'goodwill is an intangible asset and its value represents the difference between the total value of company and the sum of its tangible assets. Goodwill is a company's ability to create abnormal earnings' (Valaskova et al., 2018).

Yang (1927) defined goodwill in this study 'Goodwill and Other Intangible Assets' as follows: 'company goodwill is the sum of the present value of the future expected income of the incumbent company which the newly established company would not be able to achieve'.

In 1968, Catlett et al. published their research 'Accounting Research Study No. 10', where they defined goodwill as 'abnormal income capacity' (Ahsan et al., 2021).

In 1980, Canadian economist Edward Stamp published the study 'Corporate Reporting: Its Future Evolution', where he noted 'The problem of accounting for goodwill, especially 
The concept of economic-managerial goodwill:

International bibliographic research

Authors: Ivana Podhorska, Svitlana Bilan,

Catalin Ionita

internally generated, is probably the most entangled accounting issue and is almost insoluble. This concerns human talent, technical and other knowledge, and many other incalculable assets, making this task impossible to solve' (Cao et al., 2021).

In 1982, Peasnell described goodwill in his study 'Some Formal Connections between Economic Values and Yields and Accounting Numbers' as 'goodwill is the sum of company good reputation, which added the value to the total value of this company'.

In 1992, Arnold published a study 'Goodwill: A Problem that will not Go Away', where he described goodwill as a residual that arises after acquisition: 'residual is only a synergic effect and not a separately identifiable asset'.

In their study published in 1995 entitled 'Valuation and Clean Surplus Accounting for Operating and Financial Activities', Feltham and Ohlson stated that 'the value of the company is formed by the sum of the book value of the company equity and the present value of the expected future residual income... (...) goodwill is the present value of future residual income'.

The following quote from the study by Smith and Stanton in 1999 'Goodwill Hunting: An Examination of the Nature and Accounting Treatment of Goodwill' states that it is not acceptable to include goodwill in assets in the financial statements because of it partially reflects the judgment derived from these financial statements' (Weissova, 2016).

Maly (2002) noted that 'goodwill is the good reputation of a company in its business partners, financial institutions, public, customers... in domestic markets and abroad' (Wickert, 2021).

In 2008, Bloom in 'Double Accounting for Goodwill: A Problem Redefined' stated that 'there is a significant controversy between what goodwill is and its resources because it is an interdisciplinary issue' (Podhorska et al., 2019).

Other authors who tried to define goodwill include Suchanek (2009), who stated that 'goodwill clearly reflects company position in the market, the quality of its production, tradition, reputation in the eyes of its main customers, and so on. It is evident that it really requires a long time and considerable effort in terms of promotion' (Podhorska et al., 2019).

Interestingly, the opinion from an online paper 'Goodwill of the Company', which was published in 2015 in the Czech Republic states that 'goodwill is a good reputation of company, the loyalty of its customers, quality of employees, advantage of strategic location or outlets, organizational structure... It thus represents the amount which arises from the difference between the accounting valuation of the company and the market valuation of the company'.

Table 1 shows the timeline of the most important goodwill publications from 1884 to the present. The table provides year, authors, study tile, and publisher. 
Table 1: The timeline of the most important "goodwill publications" from 1842 - to present

\begin{tabular}{|c|c|c|c|}
\hline Year & Author & Title & Journal \\
\hline 1884 & Harris & The law and practice in relation to goodwill. & The Accountants Students Journal \\
\hline 1897 & Dicksee & Goodwill and its treatment in accounts. The Accountant. & London, Gee and Co \\
\hline 1921 & Leake & Commercial goodwill. Its history, value, and treatment in accounts. & Sir Isacc Pitman \& Sons \\
\hline 1927 & Yang & Goodwill and other intangible assets & Ronald Press \\
\hline 1953 & Nelson & The momentum theory of Goodwill. & The Accounting Review \\
\hline 1957 & Edey & Business valuation, goodwill and the super-profit method. & Studies in Accounting Theory \\
\hline 1966 & Carsberg & The contribution of P.D.Leake to the theory of goodwill valuation & Journal of Accounting Research. \\
\hline 1973 & Tearney & Accounting for goodwill: A realistic approach. & Journal of Accountancy \\
\hline 1982 & Hughes & Goodwill in accounting: A history of the issues and problems. & Georgia State University \\
\hline 1983 & Courtis & Business godwill: Conceptual clarification via accounting, legal and etymological perspectives. & The Accounting Historians Journal \\
\hline 1992 & Arnold & Goodwill: A problem that will not go away. & Trade Publication Accountancy \\
\hline 1993 & Johnson and Tearney & Goodwill - An eternal controversy & Cpa Journal \\
\hline 1994 & Chauvin and Hirschey & Goodwill, profitability and the market value of a firm. & Journal of Accounting and Public Policy \\
\hline 1995 & Clinch & Capital markets research and the goodwill debate. & Australian Accounting Review \\
\hline 1995 & Feltham and Ohlson & Valuation and clean surplus accounting for operating and financial activities. & Contemporary Accounting Research \\
\hline 1995 & Lonergan & Goodwill and bad ideas: Fact and Fiction in the amortisation debate. & Jassa \\
\hline 1997 & Casson & Ako získat' pät’násobný goodwill & ajfa + avis \\
\hline 1997 & $\begin{array}{l}\text { Shenkar and } \\
\text { Yuchtmanyaar }\end{array}$ & Reputation, image, prestige, and goodwill: An interdicsiplinary approach to organizational standing. & Human Relations \\
\hline 1997 & Zeff and Dharan & Goodwill and other intangible assets. & $\begin{array}{l}\text { Readings and Notes on Financial } \\
\text { Accounting }\end{array}$ \\
\hline 1998 & Gore et al. & Accounting for goodwill: What factors influence management preferences? & Social Science Research Network \\
\hline 1998 & Hughson & Goodwill. & British Accounting Review \\
\hline 1999 & Smith and Stanton & Goodwill Hunting. An examination of the nature and accounting treatment of goodwill. & The University of Newcastle. \\
\hline 2000 & Canibano & Accounting for intangibles: A literature review & Journal of Accounting Literature \\
\hline 2001 & Herz et al. & Equity valuation models and measuring goodwill impairment. & Accounting Horizons \\
\hline 2005 & Bone & Hunting goodwill: A history of the concept of goodwill in trademark law. & Boston University Law Review \\
\hline 2006 & Begley et al. & Modeling goodwill for banks: A residual income approach with empirical test. & Contemporary Accounting Research \\
\hline 2006 & Hvozdarova & Goodwill a jeho testovanie. & Účtovníctvo, Auditorstvo, Daňovníctvo \\
\hline 2006 & Lundholm & Discussion of „Modeling goodwill for banks: A residual income approach with empirical tests. & Contemporary Accounting Research \\
\hline 2006 & Zelenka & Goodwill principy vykazováni v podniku. & Ekopress, \\
\hline 2008 & Bloom & Double accounting for goodwill: A problem redefined. & Taylor \& Francis Group \\
\hline 2008 & Podolna & Key aspects of formation and development of positive goodwil of an enterprise. & Actual Problems of Economics \\
\hline 2008 & Wyatt & $\begin{array}{l}\text { What financial and non-financial information on intangibles is value relevant? A review of the } \\
\text { evidence. }\end{array}$ & $\begin{array}{l}\text { Information for Better Markets } \\
\text { Conference }\end{array}$ \\
\hline 2011 & Bean & Hunting goodwill: Personal goodwill as property in corporate acquistions. & $\begin{array}{l}\text { Journal of Corporate Accounting \& } \\
\text { Finance }\end{array}$ \\
\hline 2011 & $\begin{array}{l}\text { Boyarko and } \\
\text { Samusevych }\end{array}$ & Role of intangible assets in company's value creation. & Actual Problems of Economics \\
\hline 2012 & Kim et al. & Goodwill accounting and asymmetric timeliness of earnings. & Review of Accounting and Finance \\
\hline
\end{tabular}


The concept of economic-managerial goodwill:

International bibliographic research

Authors: Ivana Podhorska, Svitlana Bilan,

$2012 \quad$ Tsai

2015 Cavalinhos and

Carreira

2015 Glaum et al.

2015 Reilly

2016 Kimbro and $\mathrm{X}$

2016 Nugent

2016 Podhorska and

Siekelova

2016 Weissova

$2018 \quad$ Kliestik et al.

2019 Podhorska et al.
Determinants of intangible assets value: The data mining approach.

The impact of the goodwill in profit.

Determinants of goodwill impairment - International evidence.

Goodwill valuation approaches, methods, and procedures

The accounting treatment of goodwill, idiosyncratic risk, and market pricing.

Goodwill: The illusion of value?

The impact of internally generated goodwill on the financial performance of companies -

International comparison.

Determination the value of internally generated goodwill by using residual income valuation.

Searching for key sources of goodwill creation as new global managerial challenge.

Possibility of company goodwill valuation: Verification in Slovak and Czech Republic.
Catalin Ionita

Knowledge-Based Systems

Revista Universo Contábil.

American Bankruptcy Institute Journal Journal of Accounting, Auditing and

Finance

Journal of Business \& Economic Policy Globalization and Its Socio-Economic

Consequences

Transcom

Polish Journal of Management Studies Management \& Marketing - Challenges for the Knowledge Society

Source: Processed by authors 


\section{Methodology}

'Scientific literature saves people from ignorance, and beautiful literature saves from rude and vulgar'.

The topicality of goodwill is declared by the bibliometric analysis presented in this study. Bibliometry is a scientific discipline that deals with the quantitative aspects of production, propagation, and use of recorded information. (Tague-Sutcliffe, 1992)

Bibliometrics, informetrics, and webometrics are scientific disciplines that examine the quantitative aspects of various information in the process of creating, disseminating, and using it. The intersection of all these disciplines is methods and their application to scientific information, which is the focus of this analyses. Research on scientific information is the underlying reason for the wide application of bibliometric methods across all fields of science. Most often, bibliometry or scientometry is associated with the evaluation of science at various levels. Bibliometry, however, has a much wider application. Based on data on publications, bibliographic references, and citations, it is possible to explore historical developments in individual scientific areas and reveal the often hidden relationships between disciplines, authors, or topics. Conversely, bibliometric methods can be used to identify recent topics in scientific literature or the speed of their obsolescence. Bibliometric analysis in this study has the following features:

\section{1) Analysed databases:}
a) Web of Science
b) Scopus
c) Social Science Research Network

2) Analysed years:
a) $1912-2019$

3) Applied methods:
a) Descriptive statistics
b) Science maps

\section{4) Subject of analysis:}
a) Frequency of 'goodwill' publications in scientific databases
b) Frequency of 'goodwill' publications per country
c) Frequency of 'goodwill' publications in different fields of science
d) Keyword science map for 'goodwill' publications
e) Science maps of countries with the highest citation index of 'goodwill' publications
f) Science maps of countries which are most frequently cited 'goodwill' publications
g) Science maps of most frequently cited authors with 'goodwill' publications

\subsection{Analysed databases}

The Clarviate Analytics Web of Science (WoS) is an online database providing common access to multiple citation indexes. Currently, an online version of the Web of Knowledge platform is most widely used. Web of Science is a citation database that is updated weekly and contains records of documents from a set of monitored sources in its indexes. These can be indexed completely (cover to cover) or selectively, that is, only selected parts are indexed from the source.

SciVerse Scopus is Elsevier's largest abstract and citation database. It was created much later than the Web of Science citation indexes and launched in 2004. The records were processed retrospectively until 1996. Journals included in the database after 2004 contain records from 
The concept of economic-managerial goodwill:

International bibliographic research

Authors: Ivana Podhorska, Svitlana Bilan,

Catalin Ionita

the registration. Although the criteria of the Web of Science database are respected in the selection of indexed titles, they contain more records and are focused on European resources. Since 2009, Scopus has almost doubled its coverage of arts and humanities and provides daily updates. In addition to journals, it also monitors proceedings, patents, and websites.

The Social Science Research Network (SSRN) is a network that compiles academics and researchers and facilitates access to social science documents available through open access sources (currently more than 750000 full texts). It was founded in 1994 by Michael Jensen and Wayne Mar, financial economists. Since 2003, it has been ranked among the largest openaccess repositories in the world, measured by the number of scientific PDF files.

\subsection{Applied methods}

The Science Map is a spatial representation of the relationships between scientific disciplines, topics, and individual documents (authors) based on formal quantifiable characteristics of scientific literature at a given time. (De Bellis, 2009). Science maps provide a description of the intellectual structure of the scientific field independent of subjective decisions, spatially organise a large number of documents, which are grouped into larger interconnected units. The method is based on frequency analysis of the common occurrence of terms or keywords in titles, abstracts, and documents. Such a presentation is close to human thinking and is, therefore, often used for information retrieval. The principle of clustering similar documents is used to create science maps. Groups of similar documents create clusters that can be further joined. There are several methods to determine the similarity of documents, which can be divided into three groups: (i) text-oriented, (ii) cited-oriented, and (iii) combination. The first step involved collecting data from the Web of Science database, and subsequently analysing data for the period 1912-2019 using VOSviewer. Science maps are created using this software.

\section{Results}

Based on a bibliographic analysis of scientific databases and their content of scientific publications dealing with 'goodwill' we start with descriptive statistics. The second part of the analysis is dedicated to science maps. The results of the descriptive statistical methods used in the bibliographic analysis are shown in Figures 2-4. The results of science maps are shown in Figures 5-8.

\subsection{Descriptive statistics}

Figure 2: Frequency of "goodwill" publications in scientific databases 1912 - to present

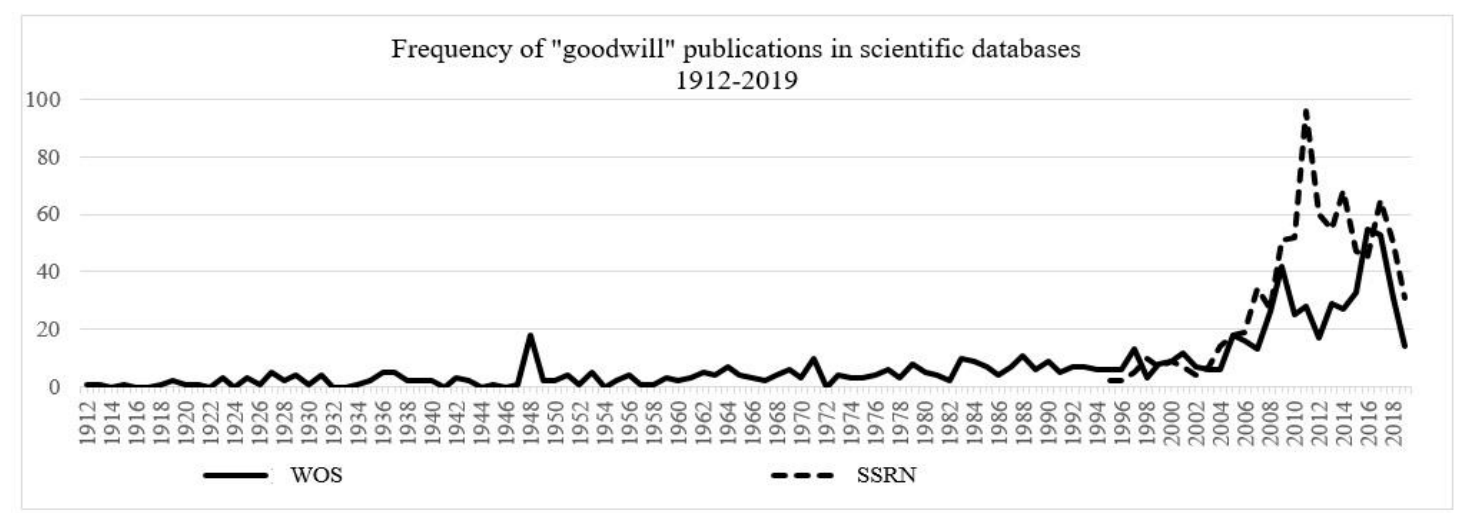

Source: Processed by authors 
The data presented in Figure 2 illustrate the timeliness of the company's goodwill, and the scientific community is showing increased interest in this topic since the past 10 years. At the beginning of the last century, the number of goodwill publications fluctuated at the level of 0 2 publications per year. At the beginning of the 21 st century, their number increased significantly. In 2000-2006 it rose to 20 goodwill publications per year. Between 2007 and 2010, 50 goodwill publications were published per year. The highest number of goodwill publications in scientific databases appeared in 2011, with almost 100 publications. Since then, there have been around 60 publications per year.

Figure 3: Frequency of "goodwill" publications per country 1912 - to present

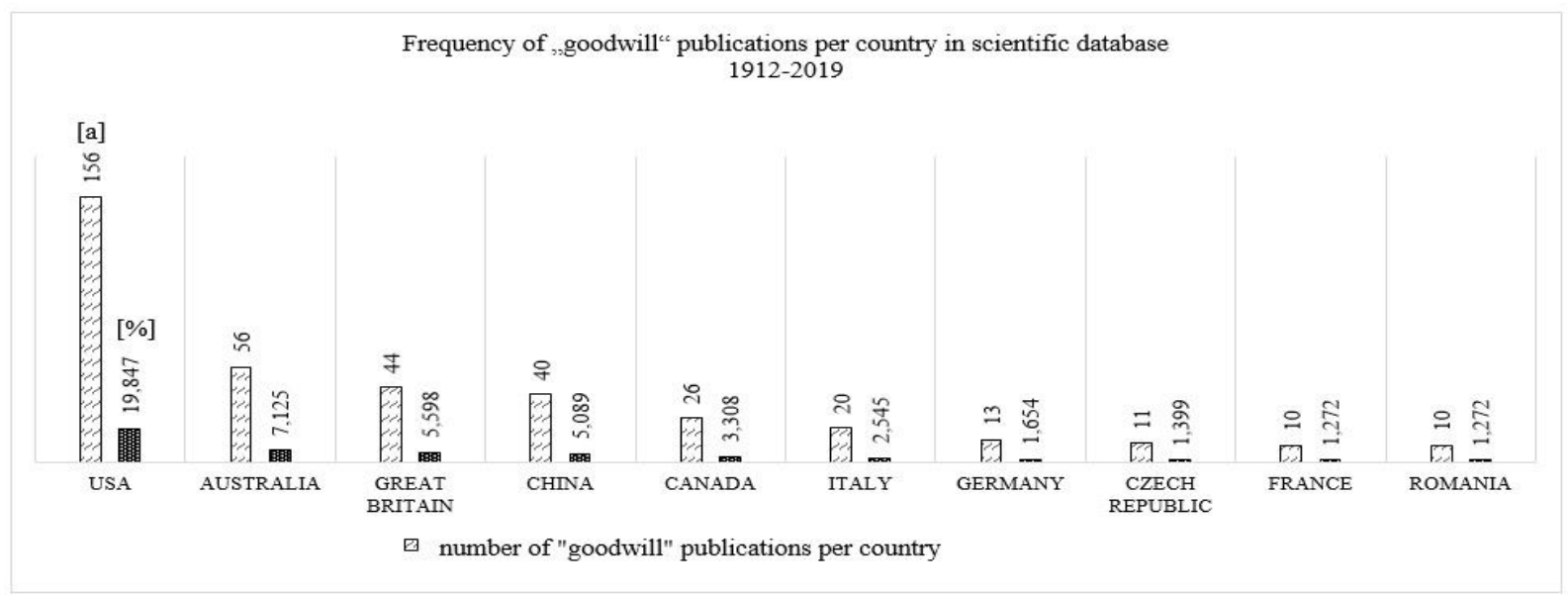

Source: Processed by authors

Figure 3 shows the number of goodwill publications per country in the WoS database for the period 1912-2019. The largest share is in the United States (US), where more than 150 goodwill publications were published in 1912-2019, representing $19.85 \%$ of the total number of goodwill publications. Australia was second with 56 goodwill publications $(7.13 \%)$. The United Kingdom (UK) was third with 44 goodwill publications during the period 1912-2019, representing $5.59 \%$. Among the European countries, Italy and Germany are also represented among the top ten countries, and the Czech Republic surprised with 11 publications (1.39\%).

Figure 4: Frequency of "goodwill” publications in different fields of science

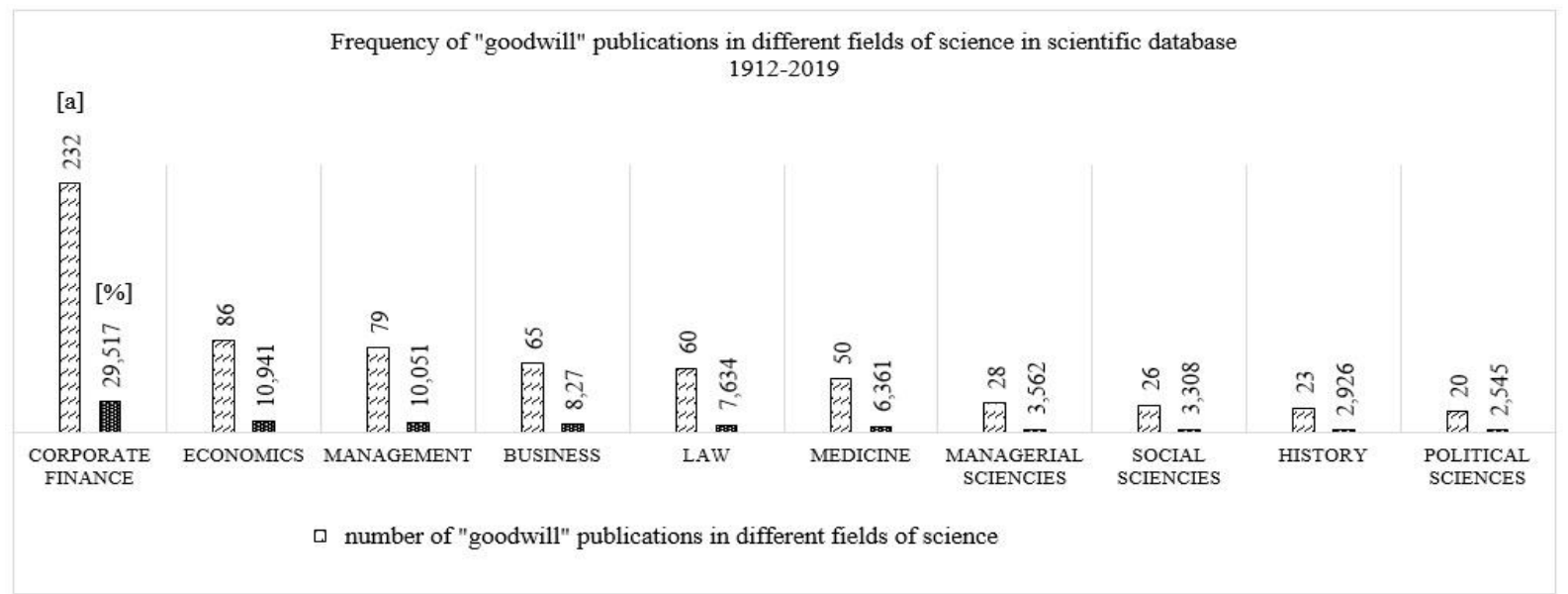

Source: Processed by authors 
The concept of economic-managerial goodwill:

International bibliographic research

Authors: Ivana Podhorska, Svitlana Bilan,

Catalin Ionita

The data captured in Figure 4 confirm that the issue of goodwill is interdisciplinary. It extends not only to typical areas of economics such as corporate finance (which has the largest share of goodwill publications, more than 200, $29.52 \%$ ), economics (86 publications, 10.94 $\%$ ), and law (60 publications, $7.63 \%$ ) social and political sciences (26 publications, $3.3 \% ; 20$ publications $2.55 \%$, respectively).

\subsection{Science maps}

Figure 5: Keyword science map for "goodwill” publications

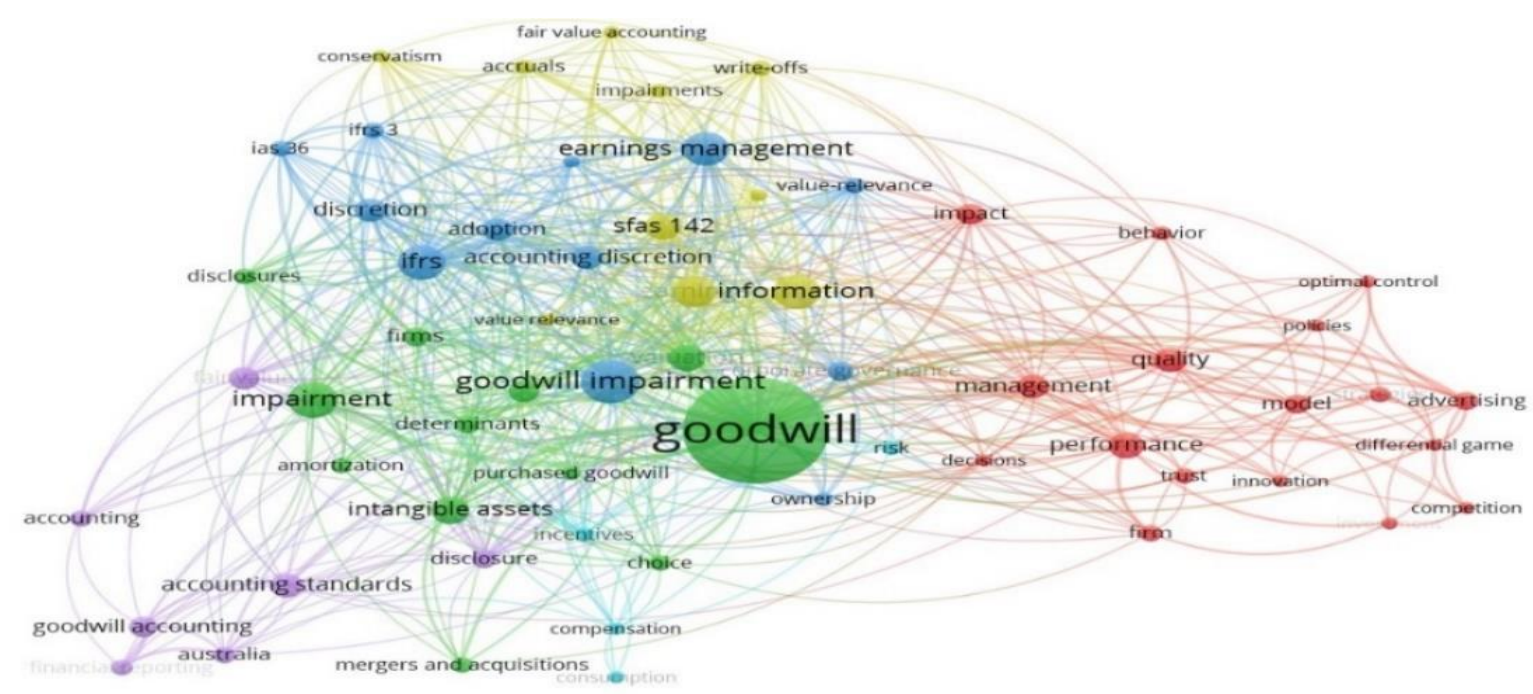

Source: Processed by authors in VOSViewer

Figure 5 shows a network visualisation (clusters) of keywords of goodwill publications. We opted to analyse keywords for the future possibility of using this information to examine factors related to goodwill. The first step involved collecting data from the WoS database, and we analysed data for the period 1912-2019 using software VOSviewer. The size of the circle represents weights, and a larger circle indicates a higher weight of the keyword. The colour of the circles determines the cluster to which the keyword belongs. Individual links are the links between items. By default, there are up to 1,000 strong links. The distance between the circles reflects the correlation of keywords in terms of correlation links, and the proximity of their relationship is stronger. It follows that publications dealing with the goodwill of a company also contains keywords such as goodwill impairment, earnings management, accounting standards, management, ownership, determinants, value, and sources. 
Figure 6: Science map of countries with the highest citation index of "goodwill" publications

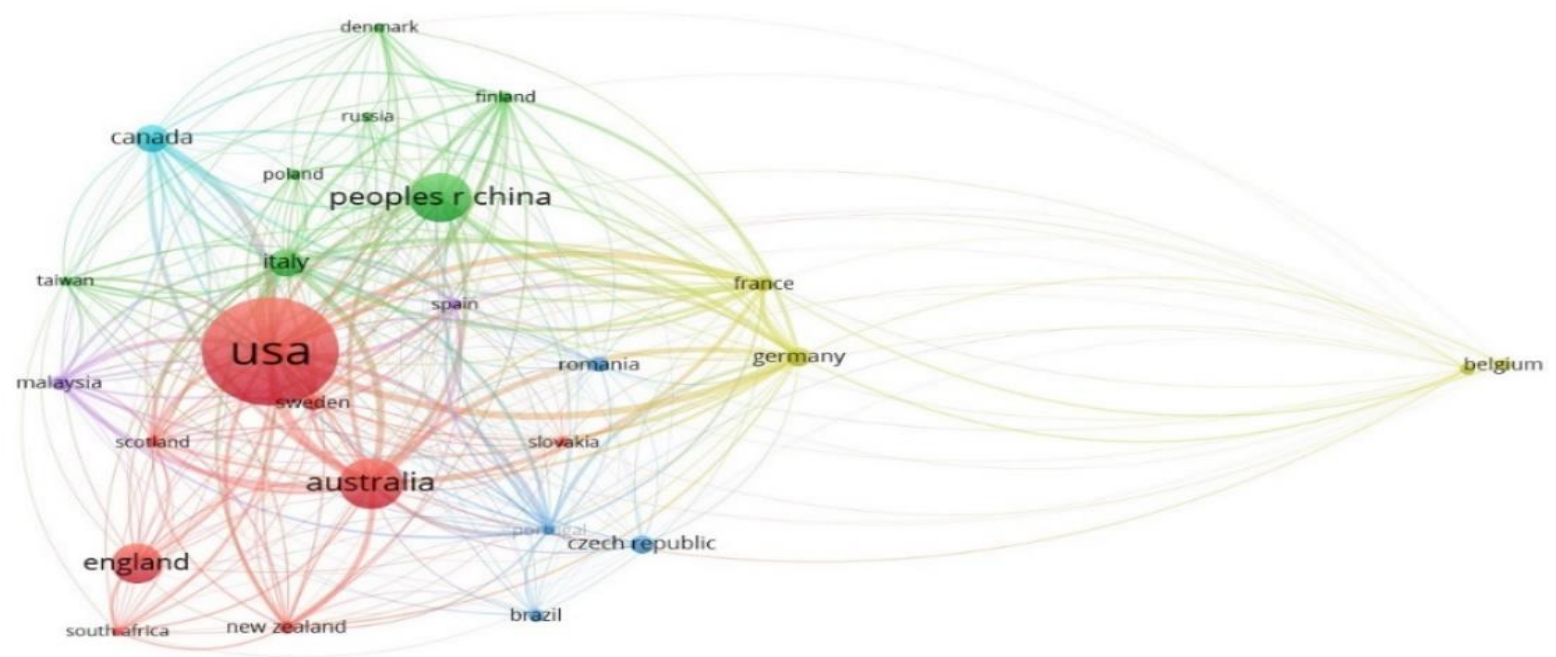

Source: Processed by authors in VOSViewer

Figure 6 shows a visualisation of the density of items represented by the country. The figure indicates the landscape origin of the goodwill publications. Each point in the item density visualisation has a colour that indicates density at that point. A large number of items in a particular heading and higher weights of citations (selectable, e.g. links between countries or number of documents) of these surrounding items - countries subsequently the colour is closer to red. Conversely, with a smaller number of items and lower weights, the colour is closer to yellow or light green. The analysis shows that the most cited goodwill publications are from the US, Australia, the UK, and China.

Figure 7: Science map of countries which the most frequently cited "goodwill" publications

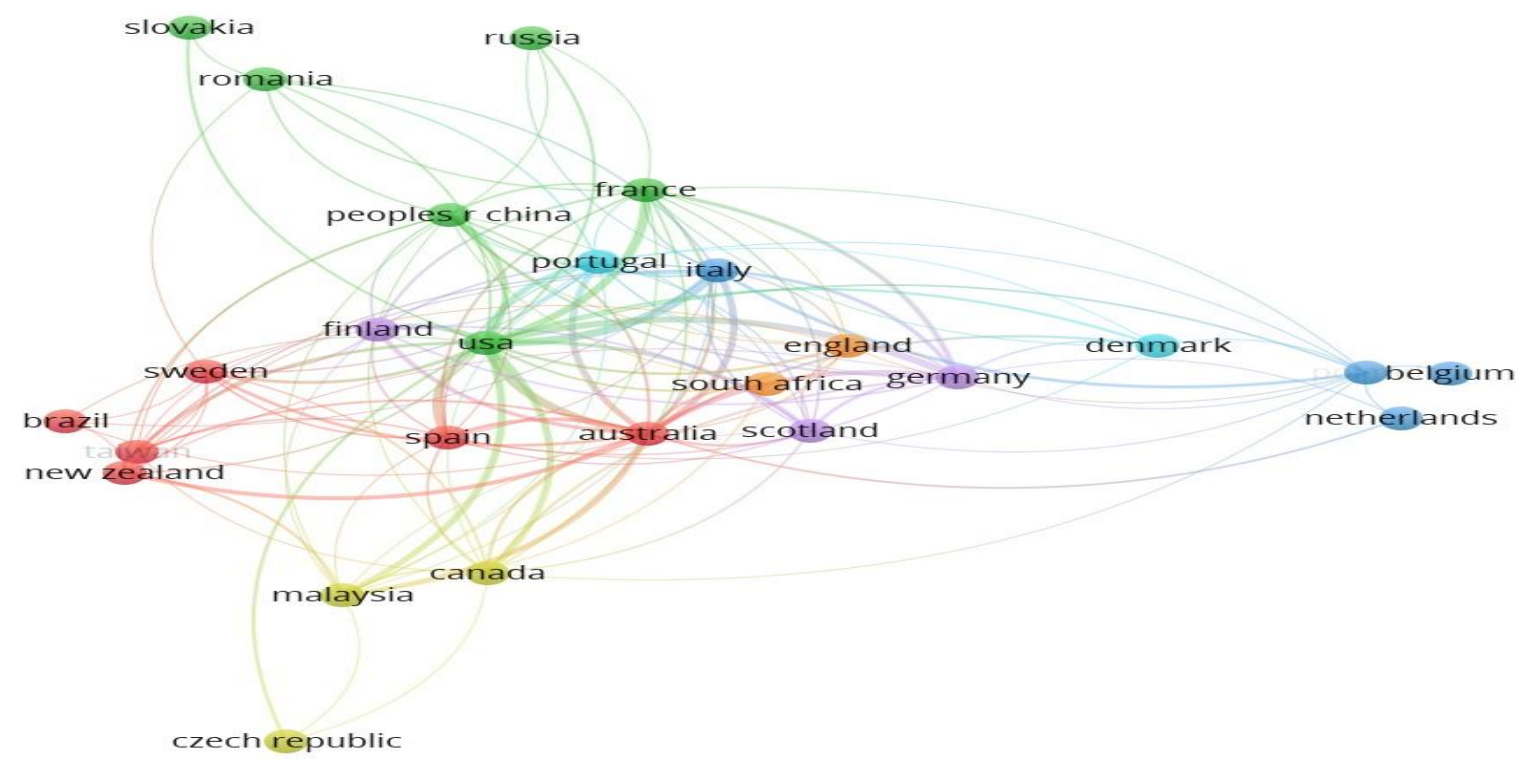

Source: Processed by authors in VOSViewer

Figure 7 shows the authors of countries with most often cited goodwill publications. Here, we can observe that while most goodwill publications have been published in the US, these publications are subsequently cited by authors from European countries. Interestingly, authors from the Slovak Republic and the Czech Republic have statistically significant representations. 
The concept of economic-managerial goodwill:

International bibliographic research

Authors: Ivana Podhorska, Svitlana Bilan,

Catalin Ionita

Figure 8: Science map of authors with the highest citation index of "goodwill" publications

comiskey (2010)

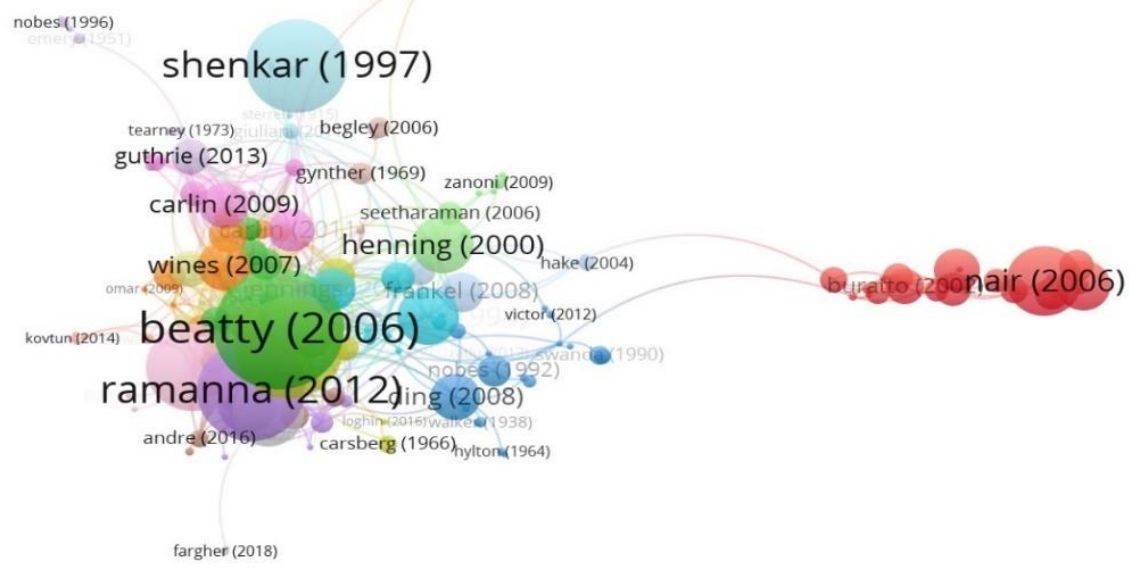

Source: Processed by authors in VOSViewer

The last science map (Figure 8) shows the most cited authors dealing with goodwill. Among the most cited authors are Shenkar (1997), Beatty (2006), Tearney (1973), and Seetharaman (2006).

\section{Discussion and conclusion}

This study focuses on internally generated goodwill because its definition and quantification are still a managerial challenge. Purchased goodwill is a familiar term in accounting and represents the amount by which the purchase price of a company is greater than the accounting amount of its assets. At the same time, its value must be identified separately, according to IAS38/EFRS3. In contrast, internally generated goodwill is more difficult to define and can help companies achieve business success. The value of goodwill may be significant, although it is not directly visible in financial statements, and it can generate future economic benefits for the company. The content $f$ internally generated goodwill is more difficult to define and quantify. The difficulty of this problem is also demonstrated by several definitions and authors dealing with this issue. Moreover, authors have different perspectives. The authors agree that it is difficult to pinpoint all sources of goodwill and the factors that affect it. Image, reputation, brand, customer loyalty, employees, strategic location, public relations, research and development expenditure, advertising expenditure are most commonly found in the literature as potential sources of goodwill value. These conclusions are consistent with authors such as Arnold (1922), Peasnell (1982), and Shenkar and YuchtmanYarr (1997). Goodwill has been built over many years but can be lost due to a single wrong move. In addition, many authors agree that goodwill is an intangible asset (e.g. Tearney 1973).

The subject of goodwill is a topic discussed in scientific communities, as demonstrated by the number of goodwill publications per year. At the beginning of 20th century (1912), the number of goodwill publications fluctuated at the level of 0-2 publications per year, but by the start of the 21st century their number increased significantly. During the period 2000-2006, there were 20 goodwill publications per year. Between 2007 and 2010, 50 goodwill publications were published per year. The highest number of goodwill publications in scientific databases has so far appeared in 2011, with almost 100 publications. This topic is also interdisciplinary and extends to not only typical areas of economics, such as corporate finance (with the largest share of goodwill publications, more than 200, representing $29.52 \%$ ), economics (86 
publications, $10.94 \%$ ), law (60 publications, $7.63 \%$ ), and social and political sciences $(26,3.3$ $\%$; 20 publications, $2.55 \%$, respectively), during the period 1912-2019. Among the most cited authors dealing with the subject of goodwill is Shenkar (1997); Tearney (1973) also has several publications.

This study mainly aims to provide a historical review of the scientific literature dealing with the subject of goodwill from 1842 to the present. The study has analysed scientific databases such as Web of Science, Scopus, and Social Science Research Network. The study methods included descriptive statistics and science maps. The study applied VOSviewer software for extracting data. The results provided a holistic view on the evolution of goodwill in the scientific community and demonstrate its significant role in the world of science. Finally, we conclude that this study mainly aims to provide a holistic overview of the genesis of goodwill in the scientific community and demonstrate its significant role in the world of science. This study provides a historical review of the scientific literature dealing with goodwill from 1842 to the present.

Author contributions: All authors listed have made a substantial, direct and intellectual contribution to the work, and approved it for publication.

Funding: This research received no external funding.

Data Availability Statement: Data was obtained from scientific databases Web of Science and Scopus.

Conflicts of Interest: The authors declare no conflict of interest.

\section{References}

Ahsan, F. M., Faud, M., \& Sinha, A. K. (2021). Seeking strategic assets within cross-border acquistion waves: A study of Indian firms. Journal of International Management, 27(4).

Andersson, O., Carlson, J. I., \& Wengstrom, E. (2021). Differences attract: An experimental study of focusing in economic choice. Economic Journal, 131(639), 2671-2692.

Andrews, D., \& de Serres, A. (2012). Intangible assets, resource allocation and growth: A framework for analysis. Working Pap, OECD , Economic Department.

Arnold, J. (1992). Goodwill: A problem that will not go away. Trade Publication Accountancy, 109(1186), 35.

Augier, M., \& Teece, D. (2005). An economic perspective on intellectual capital. In B. Marr (Ed.), In Perspective on Intellectual Capital: Multidisciplinary Insight into Management, Measurement, and Reporting. 1th Ed, pp. 3-27. Oxford: Elsevier Inc.

Bean, L. A. (2011). Hunting goodwill: Personal goodwill as property in corporate acquisitions. Journal of Corporate Accounting \& Finance, 23(2), 55-61.

Begley, J., Chabmerlman, S. L., \& Li, Y. H. (2006). Modeling goodwill for banks: A residual income approach with empirical tests. Contemporary Accounting Research, 23, 31-68.

Bhandari, A., \& McGrattan, E. R. (2021). Sweat ekvity in US private business. Quarterly Journal of Economics, 136(2), 727-781.

Bone, G. R. (2005). Hunting goodwill: A history of the concept of goodwill in trademark law. Boston University Law Review, 84, 547-622.

Boyarko, I. M., \& Samusevych, Y. V. (2011). Role of intangible assets in company's value creation. Actual Problems of Economics, 117, 86-94.

Canibano, L. et al. (2000). Accounting for Intangibles: A literature review. Journal of Accounting Literature, 102130.

Cao, R. Q., Koning. R. M., \& Nanda, R. (2021). The hidden bias in crowdfunding platforms. Harvard Business Review, 99(6), 26-27.

Carsberg, V. B. (1966). The contribution of P. D. Leake to the theory of goodwill valuation. Journal of Accounting Research, 4(1), 1-15. 
The concept of economic-managerial goodwill:

International bibliographic research

Authors: Ivana Podhorska, Svitlana Bilan,

Catalin Ionita

Clinch, G. (1995). Capital markets research and the goodwill debate. Australian Accounting Review, 5(9), 22-30.

Corbae, D., \& D'Ersamo, P. (2021). Reorganization or liquidation: Bankruptcy choice and firm dynamics. Review of Economic Studies, 88(5), 2239-2274.

Courtis, J. K. (1983). Business goodwill: Conceptual clarification via accounting, legal and etymological perspectives. The Accounting Historians Journal, 10, 1-38.

De Bellis, N. (2009). Bibliometrics and Citation Analysis: From the Science Citation Index to Cybermetrics. Toronto: The Scarecrow Press, Inc.

Edey, H. C. (1957). Business valuation, goodwill and the super-profit method. Studies in Accounting Theory, 68(15-18), 52-54.

Feltham, G., \& Ohlson, J. A. (1995). Valuation and clean surplus accounting for operating and financial activities. Contemporary Accounting Research, 11(2), 689-731.

Gardberg, N., \& Fombrun, C. (2006). Corporate citizenship: Creating assets across institutional environments. Academic Management Review, 31, 329-346.

Gore, Taib, \& Taylor (1998). Accounting for goodwill: What factors influence management preferences? WP 98/014. Available at SSRN.

Gupta, A., \& Van Nieuwerburgh, S. (2021). Valuing private ekvity investments strip by strip. Journal of Finance, 76(6), 3255-3307.

Harris, W. (1884). The law and practice in relation to goodwill. The Accountants 'Students Journal, $256-263$.

Herz, R. H. et al. (2001). Equity valuation models and measuring goodwill impairment. Accounting Horizons, 15, $161-170$

Hughson, C. (1998). Goodwill. British Accouting Review, 30(2).

Ionita, C., \& Dinu, E. (2021). The effect of intangible assets on sustainable growth and firm value - Evidence on intellectual capital investment in companies listed on Bucharest Stock Exchange, Kybernetes, 50(10), 28232849.

Chauvin, K. W., \& Hirschey, M. (1994). Goodwill, profitability, and the market value of a firm. Journal of Accounting and Public Policy, 13(2), 159-180.

Janoskova, K., \& Kral, P. (2019). An in-depth analysis of the summary innovation index in the V4 countries. Journal of Competitiveness, 11(2), 68-83.

Kim, X., Lee, Ch., \& Yoon, W. S. (2012). Goodwill accounting and asymmetric timeliness of earnings. Review of Accounting and Finance, 12(2), 112-129.

Kimbro, M. B., \& Xu, D. (2016). The accounting treatment of goodwill, idiosyncratic risk, and market pricing. Journal of Accounting Auditing and Finance, 31, 365-387.

Kliestik, T., Kovacova, M., Podhorska, I., \& Kliestikova, J. (2018) Searching for key sources of goodwill creation as new global managerial challenge. Polish Journal of Management Studies, 17(1), 144-154.

Leake, P. D. (1921). Commercial goodwill. Its history, value, and treatment in accounts. London: Sir Isacc Pitman \& Sons, Ltd.

Lonergan, W. (1995). Goodwill and bad ideas; fact and fiction in the amortisation debate. Jassa, 4, 2-7.

Lundholm, R. J. (2006). Discussion of „Modeling goodwill for banks: A residual income approach with empirical tests“. Contemporary Accounting Research, 23(1), 69-71.

Mooney, K. (2008). The Essential of Accounting Dictionary. Naperville, IL, USA: Sphinx Publishing.

More, F. (1891). Oxford english dictionary - wills and inventories of the northern counties of England (publication of the Surtees Society, 1835) 352, „I gyue to John Stephen... my whole interest and good will of my Quarell“, Reproduced in The Accountant, 1828 et seq.

Nelson, H. R. (1953). The momentum theory of goodwill. The Accounting Review, 28, 491-499.

Nugent, H. J. (2016). Goodwill: The illusion of value? Electronic version. Journal of Business \& Economic Policy, $3(3)$.

Ocak, M. and Findık, D. (2019), “The impact of intangible assets and sub-components of intangible assets on sustainable growth and firm value: evidence from Turkish listed firms", Sustainability, Vol. 2019 No. 11, p. 5359. 
Peasnell, K. (1982). Some formal connections between economic values and yields and accounting numbers. Journal of Business Finance \& Accounting, 9(3), 361-381.

Podhorska, I., \& Siekelova, A. (2016). The impact of internally generated goodwill on the financial performance of companeis - International comparison. Proccedings of the 16th International Scientific Conference on Globalization and Its Socio-Economic Consequences, Rajecke Teplice, Slovak Republic, 1736-1743.

Podhorska, I., Valaskova, K., Stehel, V., \& Kliestik, T. (2019). Possibility of company goodwill valuation: Verification in Slovak and Czech Republic. Management \& Marketing - Challenges for the Knowledge Society, 14(3), 338-356.

Reilly, R. F. (2015). Goodwill valuation approaches, methods, and procedures“. American Bankruptcy Insitute Journal, 34, 10-24.

Shenkar, O., \& Yuchtmanyaar, E. (1997). Reputation, image, prestige, and goodwill: An interdisciplinary approach to organizational standing. Human Relations, 50, 1361-1381.

Siegel, J., \& Shim, J. (2000). Dictionary of Accounting Terms (Vol. 1th ed). New York, NY, USA: Barron's Educational Series

Tague-Sutcliffe, J. (1992). An introduction to informetrics. Information Processing and Management: An International Journal, 28(1).

Tearney, M. G. (1973). Accounting for goodwill: A realistic approach“. Journal of Accountancy, 136(1), 41-45.

Tsai, C. F. (2012). Determinants of intangible assets value: The data mining approach. Knowledge-Based Systems, 31, 67-77.

Valaskova, K., Kliestikova, J., \& Krizanova, A. (2018). Consumer perception of private label products: An empirical research. Journal of Competitiveness, 10(3), 149-163.

Weissova, I. (2016). Determination the value of internally generated goodwill by using residual income valuation. Transcom, 11th European Conference of Young Researchers and Scientists, Zilina, Slovak Republic, 288-292.

Wickert, C. (2021). Corporate social responsibility research in the Journal of Management Studies: A shift from a business-centric to a society-centric focus. Journal of Management Studies, 58(8), E1-E17.

Wyatt, A. (2005). Accounting recognition of intangible assets: Theory and evidence on economic determinants. Accounting review, 80, 967 - 1003. 